\title{
EFFECT OF OSMOTIC DEHYDRATION ON PHYSIOCHEMICAL PROPERTIES OF RED CARROTS
}

\author{
EL-WASEIF., K.H.M., M.R.M. MASOUD. and EL. M. EL-SAEEDY
}

Food Technology Research Institute Agricultural Research Center

(Manuscript received $1^{\text {st }}$ July 2012)

\begin{abstract}
This study was carried out to assess the quality parameters of osmo-dried red carrots pretreated with various types of osmotic sucrose syrup i.e. $40 \%, 50 \%, 60 \%$ and $70 \%$ sucrose syrup, compared with those produced by untreatedred carrots(control). The sucrose syrup $70 \%$ had the lowest osmosis time for osmosedcarrots followed by $60 \%, 50 \%$, and $40 \%$ sucrose syrup respectively. However, the reduction time of dehydration for both red carrots caused the increase in solid gain (SG) and total solids (T.S) than that obtained bythe control (untreated) drying. Furthermore, the dehydration parameters (WL and WC) were strictly related to the type and concentration of the used osmosis solution. The phsico-chemical properties, microbiological assessment and quality attributes of both osmo-dried and controlred carrotsjust after processing and during storage for 6 months were also undertaken. Results indicate that, osmo-dried red carrotspretreated with sucrose syrup $70 \%$ had the highest retention of ascorbic acid followed by $60 \%, 50 \%$ and $40 \%$ sucrose syrup, respectively. Reducing sugars content ranged between 51.69 to $56.50 \%$ for osmos-dried red carrotswith various pretreatments just after processing. While, the corresponding values of fibers ranged from 9.53 to $9.75 \%$ respectively. The control- dried carrots had the highest total microbial counts $(9.1 \times 102 \mathrm{cfu} / \mathrm{g})$ followed by osmo-dried pretreated with sucrose syrup $40 \%$ (6.3x 102cfu/g), 50\% sucrose syrup (5.2 x102cfu/g), $60 \%$ sucrose syrup $(3.7 \times 102 \mathrm{cfu} / \mathrm{g})$ and $70 \%$ sucrose syrup (2.6 $\mathrm{x} 102 \mathrm{cfu} / \mathrm{g})$, respectively. On the other hand, all tested counts of microorganisms either total counts of bacteria or yeasts and molds showed proportional reduction with extending the storage period and reached to the maximum reduction after 6 months of storage. The osmo-dried red carrotspretreated with sucrose syrup $70 \%$ recorded the highest scores of color, texture, taste, flavour and overall acceptability followed by osmo-dried samples pretreated with $60 \%, 50 \%$ and $40 \%$ sucrose syrup and the un treated (control) just after processing and after 3 and 6 months of storage at ambient temperature. Therefore, pretreatment of carrots with osmotic sugar solution to produce osmo-dried product played an important role for producing high quality dried red carrotsthan those produced by the control drying process.
\end{abstract}




\section{INTRODUCTION}

Osmotic dehydration is the process in which water is partially removed from the cellular materials when these are placed in a concentrated solution of soluble solute. Osmotic dehydration, which is effective even at ambient temperature, preserves the color, flavour and texture of food from heat, and is used as a pre-treatment to improve the nutritional, sensorial and functional properties of food. The amount of water remaining in the material after osmotic dehydration, however, does not ensure its stability, as water activity is generally higher than 0.9 . When shelf stability is an ultimate process objective, other, complementary methods of water removal, such as convective drying, freeze drying, freezing, etc. are suggested Valiaet,al(2009)Carrots originated from Middle Asia, where it has been known for 3000 years and nowadays, it is cultivated in Europe, Turkey and many countries [Schwarz et,al. (2004).].Red carrotsanthocyanins comprise high amount of acylatedcyanidin derivatives (41.0\%) which exhibit remarkable stability to $\mathrm{pH}$ value changes and heat treatment Stintzing et.al,(2002)showed that acylatedanthocyanins are protected from the hydrophilic attack of water molecules by the acyl moieties (intramolecular effect). Beside improving the stability, the acylatedanthocyanins display enhanced biological activities, anthocyanins possess strong radical-scavenging,antimutagenic activities and anti-hypertensive effects.Anthocyanins have been reported to exert cancer chemo preventive activity $\mathrm{Hou}(2003)$. Contrary to grape skin, red carrots contain low amounts of non-anthocyanin phenolics which causehazing and precipitation in clear fruit juices. Moreover, red carrotsanthocyanins give an excellent bright strawberry red shade at acidic $\mathrm{pH}$ values, therefore, red carrotsjuice can be consideredas good choice for coloring fruit juices, nectars, softdrinks, jellies and confectioneries.Alasalvar et. al.., (2001) reported that red carrots contain a high amount of nutraceutical components. Furthermore, Netzel et. al.. (2007)proved that anthocyanin extracted from red carrotsinhibited proliferation of human cancer cells (colorectal adenocarcinoma and promyelocytic leukemia) in a dose dependent manner..The process of osmotic dehydration can be used for the preparation of shelf-stable products for the purpose of using during off-season. The quality of promisedcarrots is much superior to the product dehydrated with theconventional method of convective dehydration.Red carrots (Daucuscarota L.) is one of the important root vegetable crops and is highly nutritious as it contains appreciable amounts of vitamins B1, B2, $B 6$ and $B 12$ besides being rich in $\beta$-carotene. It also contains many important minerals. $\beta$-Carotene is a precursor of vitamin $A$ and is reported to prevent cancer . The osmotic dehydration (OD) enables the water removal from the food by immersing 
the product in a hypertonic solution (of certain solutes). A water transfer takes place from the food product to the solution and a solid transfer from the solution to the food product (Matusek and Méresz, 2002). In this regard, the osmotic treatments, previous to air-drying process (Rastogi et. al.., 2004 andRevaskar et. al.., 2007) improve the nutritional, sensory and functional characteristicsof dehydrated food products. They may even improve the texture and the stability of pigments during the dehydration and storage of dehydrated products. Osmotic dehydration can be used to remove water from heat-sensitive products with low energy consumption at a low temperature. Since osmotic dehydration cannot remove moisture to a level that will prevent microbial growth, it is good as a preliminary partial dehydration step. While osmotic dehydration is a simultaneous process of water flow out and solid gain from osmotic agents, the gaining of osmotic agent can represent an added value in improving nutritional, sensorial and functional properties of the dried food.Singh et. al.., 2006 and Górnicki and Kaleta, 2007).

The objective of this investigation to study the effect of using various osmotic sucrose syrups as pretreatments for producing osmo-dried red carrotson dehydration parameters, physicochemical properties and microbial assessment as well as sensory evaluation was undertaken and during the storage for 6 month at ambient temperature.

\section{MATERIALS AND METHODS}

\section{Materials}

Redcarrots (Daucuscarota L) were obtained from El- Obour market, El- Obour city, Cairo, Egypt, at season 2011.

\section{Methods}

\section{Preparation of red carrots}

The red carrots were washed and peeled manually. The green parts of the carrots were removed to retain the uniform quality of the final product. Carrots were cut into slices

. The carrotsslices were washed withfresh water to remove the carrots fines adhering to the surface of the carrots, blanched at $90^{\circ} \mathrm{C}$ for $3 \mathrm{~min}$., and then cooled with water. After that, eachpart was divided into 5 groups (T1, T2, T3, T4 and T5) carrots

\section{Osmotic Dehydration}

T1, T2, T3 and T4 were immersed in solutions of 40, 50, 60 and 70\% sucrose syrup in the presence of $1 \%$ calcium chloride at $50^{\circ} \mathrm{C}$ for $12 \mathrm{hr}$. At the end of immersion the syrups were drained, and can be re-concentrated and re-used as osmotic agent for 
another osmotic process. While, the samples after draining rinsed quickly in a stream of tap water and blotted with tissue to remove the adhering solution. The obtained samples ( $T 1, T 2, T 3, T 4$ and $T 5$ control) were then weighed and dried in an oven at $50^{\circ} \mathrm{C}$ for about $23-32 \mathrm{hr}$. according to type of osmosis solution used for pretreatment.

\section{Packaging and storage}

Samples were packed in poly ethylene bags of about $100 \mathrm{~g}$ capacity with removing the air. Finally bags were sealed by heat and stored for 6 month at ambient temperature.

\section{Analytical methods}

The following variables were determined as described by Lerici et. al. (1985) for each sample: \% water content (WC), water loss (WL), solid gain (SG) as $\mathrm{g} / 100 \mathrm{~g}$ fresh product, weight reduction (WR) and total solids\% (T.S).

\section{Physico- chemical analyses}

Moisture content, total solids, ascorbic acid, total titratable acidity, total sugars, (reducing and non-reducing sugars), ash and crude fibers contents were determined according to theA.O.A.C. (1995).

\section{Microbial analysis}

Samples were serially diluted and plated on total count agar for total bacteria counts and on acidified ( $10 \%$ tartaric acid) potato dextrose agar for mold and yeast counts. Plates were incubated for $48 \mathrm{hr}$ at $30^{\circ} \mathrm{C}$ for total bacteria, and for 5 days for molds and yeasts (APHA 1992).

\section{Sensory evaluation}

The method of sensory evaluationwas carried out by using five sensory characteristics (color, texture, taste, flavor and overall acceptability) of the osmotic dehydration and control dried carrots were performed by 10 trained panelists, assigned a score of each sensory characteristic according to 10 point category scales.

\section{Statistical analysis}

Statistical analysis was done by using the SAS statistical program (SAS, Statistical analysis system 1996)

For sensory evaluation was expressed as the mean values. To ascertain the significance among means of the treatments Duncan's multiple range was tested at significant level of $P<0.05$. 


\section{RESULTS AND DISCUSSION}

Chemical constituents of redcarrots are presented in table (1). It could be noticed that fresh redcarrots contain $86.40 \%$ moisture content, $0.65 \%$ protein , $0.15 \%$ fat,6.80 \%reducing sugar , $8.62 \%$ total sugars , 1.25 ash and $2.53 \%$ crude fiber. On the other hand ,the total acidity in redcarrots was 0.25 while ,the ascorbic acid,total anthocyanin,calcium,phosphorus and iron were $60.25,170,35,30$ and $0.80 \mathrm{mg} / 100 \mathrm{~g}$ fresh carrots

Table 1. Chemical constituents of fresh red carrots

\begin{tabular}{|l|c|}
\hline \multicolumn{1}{|c|}{ Constituents } & Value \\
\hline Moisture \% & 86.40 \\
\hline Total solids \% & 13.60 \\
\hline Protein \% & 0.65 \\
\hline Fat \% & 0.15 \\
\hline Total carbohydrates \% & 9.07 \\
\hline Total sugar \% & 8.62 \\
\hline Reducing sugar \% & 6.80 \\
\hline Fiber \% & 2.53 \\
\hline Ash \% & 1.20 \\
\hline Ascorbic acid $\mathrm{mg} / 100 \mathrm{~g}$ & 60.25 \\
\hline Total acidity & 0.25 \\
\hline Total anthocyaninmg/100g & 170 \\
\hline Calcium $\mathrm{mg} / 100 \mathrm{~g}$ & 35 \\
\hline Phosphorus $\mathrm{mg} / 100 \mathrm{~g}$ & 30 \\
\hline Iron $\mathrm{mg} / 100 \mathrm{~g}$ & 0.80 \\
\hline
\end{tabular}

Dehydration parameters of osmotic dried red carrots are shown in Table (2). The Brix concentration of T1,T2,T3and T4 solutions used for osmosis were 40,50,60 and 70 Brix just before processing of red carrotsat temperature $50^{\circ} \mathrm{C}$. However, the concentration of osmoses solutions used for osmotic processing were lowered the end of osmosis to become 35, 45, 52 and 60 Brix forT1,T2,T3and T4 solutions, respectively. This phenomenon presumably owing to the reduction of water diffusion coefficient in the product- solution interface as explained by (Lerici, et. al., 1985). The osmosis timechanges the driving force of the drying process as the alteration of the type of osmosis solution.Meanwhile,thesolution of T4 had the lowest osmosis time for osmosis carrots followed by $\mathrm{T} 3, \mathrm{~T} 2$, T1and T5, respectively.Its worth to know that, the sugars in the fruits were considered as a distinctively characteristics of the fruit varieties. As the equilibration time increase, the ratios between the various components showed considerable changes (Giangiacomo et. al., 1987 and Salem and Hegazi 1973). 
Consequently, the higher weight reduction of osmosis- dehydrated redcarrots was obtained with T4, followed by T3 (69.5\%) T2 (69.7\%) and T4 (67.3\%), respectively compared with $74.8 \%$ for T5 control carrots product.However, dehydration parameters WL and WC were strictly related to the type and concentration of the osmotic solution used. The weight loss of osmosis carrots with T4 recorded the lowest one followed by $\mathrm{T} 3, \mathrm{~T} 2$ and $\mathrm{T} 1$, respectively but a reversible trend was observed between the values of WC and osmotic solutions used for processing of osmosis dried carrots. It is interesting to observe that under the investigated conditions of osmotic conditions, the reduction time for dehydration can give a higher percent of T.S in the final products of osmosed dried carrots depending upon the type of osmotic solutions used. Results also indicated that, the pretreated osmosis dried carrots with osmosis syrups before drying increased the obtained solid gain than that for the untreated samples (control). Furthermore, the osmosis dried carrots pretreated with T4 had the highest solid gain followed by $\mathrm{T} 3, \mathrm{~T} 2, \mathrm{~T} 1$ and $\mathrm{T} 5$ respectively. These results may be explained by Taiwo et. al., (2001) and Tedjo et. al., (2002) who mentioned that, solid uptake during osmotic dehydration (OD) may not necessarily be a function of permeabilized cells alone but may also depend on the type of chemical and structural changes caused by the pretreatments. Also, the osmosis process reduced the time of dehydration of grapes compared with grapes dried with sun drying may be due to the choice of osmosis solution and the addition of $\mathrm{NaCl}$ to osmotic solutions which increased the driving force of the drying process. These results are correlated well with (Lerici et. al. 1985).

Table 2. Initial concentration of osmotic solution ( ${ }^{\circ}$ Brix) as well as conditions applied for drying and characteristics of osmotic redcarrots

\begin{tabular}{|c|c|c|c|c|c|c|c|c|c|}
\hline \multirow{3}{*}{$\begin{array}{l}\text { Processing } \\
\text { conditions }\end{array}$} & \multirow{2}{*}{\multicolumn{2}{|c|}{$\begin{array}{l}{ }^{\circ} \text { Brix for } \\
\text { treatment }\end{array}$}} & \multicolumn{7}{|c|}{ Characteristics of osmosis red carrots } \\
\hline & & & \multirow{2}{*}{$\begin{array}{l}\text { Immersion } \\
\text { time (hrs) } \\
\text { of osmosis }\end{array}$} & \multirow{2}{*}{$\begin{array}{l}\text { WL } \\
(\%)\end{array}$} & \multirow{2}{*}{$\begin{array}{l}\text { WR } \\
\text { (\%) }\end{array}$} & \multirow{2}{*}{$\begin{array}{l}\text { WC } \\
\text { (\%) }\end{array}$} & \multirow{2}{*}{ SG } & \multirow{2}{*}{ 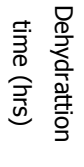 } & \multirow{2}{*}{$\begin{array}{c}\mathrm{WL}+\mathrm{SG} \\
(\%)\end{array}$} \\
\hline & Before & After & & & & & & & \\
\hline T1( $40 \%$ sucrose) & 40 & 35 & 12 & 38.9 & 67.3 & 10.3 & 24.3 & 30 & 63.2 \\
\hline $\mathrm{T} 2$ ( $50 \%$ sucrose) & 50 & 45 & 12 & 40.6 & 69.0 & 10.1 & 25.1 & 27 & 65.7 \\
\hline T3( $60 \%$ sucrose) & 60 & 52 & 12 & 41.3 & 69.5 & 10.0 & 25.5 & 28 & 66.8 \\
\hline $\mathrm{T} 4(70 \%$ sucrose $)$ & 70 & 60 & 12 & 50.3 & 70.0 & 9.90 & 26.4 & 24 & 76.7 \\
\hline T5 control & & - & - & - & 74.8 & 9.93 & 18.7 & 37 & - \\
\hline
\end{tabular}

- WL: water loss, WR: weight reduction, WC: water content, SG: solid gain.

** Values are the mean of three independent determinations. 


\section{Effect of storage period on physico- chemical properties of osmosis dried red carrotsfor 6 month at ambient temperature}

Effect of storage period up to 6 months at ambient temperature on physicochemical properties of both osmo-dried and untreated red carrots are shown in Table (3). Results indicate that, the moisture content was 86.40 for fresh carrots. While the average ratios of moisture contents of osmo-dried red carrots pretreated with different osmosis solution just after processing were 15.11 to $15.75 \%$ but it was 15.88 for the control carrots. Also, a little increment in moisture contents were recorded with progress of storage period for all tested samples and reached to the maximum at the end of storage after 6 months of storage at ambient temperature, but still being little than that T5 control carrots after 6 months.

Total solids of fresh red carrots were $13.6 \%$. While, the total solids ranged from 84.89 to $84.25 \%$ for osmo dehydrated red carrots just after processing, respectively.. Subsequently, a little increment in total solids for osmo-dried red carrotswas found as affectedby the progressive period of storage up to 6 months and its impacts by the type of osmotic solution used for retreating of both carrotssamples before drying.

The stabilization of ascorbic acid during processing is important not only from the nutritional point of view but also because ascorbic acid degradation accelerates non enzymatic browning reaction, which not only cause changes in color but can affect flavour adversely (Paakkomen and Mattiala 1991). According to El-Gharably et.al., (2009),, the main mechanisms of vitamin C losses appear to be due to water solubility and mass transfer, heat sensitivity, and enzymatic oxidation.

The content of ascorbic acid was $60.25 \mathrm{mg} / 100 \mathrm{~g}$ on fresh weight basis for red carrotsas shown in (Table3). Meanwhile, the ascorbic acid contents ranged from 89.20 to $94.32 \mathrm{mg} / 100 \mathrm{~g}$ on dry basis for osmo-dried red carrots immediately after processing, respectively. However red carrots pretreated with T4 had the highest ascorbic acid content immediately after processing followed by T3, T2and T1, respectively. But T5 control carrots had the highest ascorbic acid content compared to that in osmo dehydrated red after processing. The ascorbic acid content decreased gradually with increasing the time of storage for both osmo dehydrated and control samples by extending the storage periods up to 6 months but the greatest reduction was observed for control samples. The reduction of ascorbic acid for osmo-dried red carrots may be due to the native content of, ascorbic acid in carrots, the type of osmosis solutions used, the immersing time in osmosis solution, the temperature of dehydration process and extending shelf life at ambient temperature. These results coincide with Shastry and Hartel (1996) and El-Gharably et. al., (2009) who 
mentioned that, during the first four months of osmo dehydrated cherries there was a decrease in ascorbic acid, while in the last two months, a further decrements were found.

The initial total acidity of fresh red carrots was $0.25 \%$ whereas, the same of theosmodehydrated carrots pretreated with different tested osmosis solutions were in the range of $1.11-1.21 \%$, respectively. Just after processing depends on the choice of osmosis solution for pretreatment before drying. However, the control carrots recorded titratable acidity of $1.01 \%$.

On the other hand, findings in Table (3) show that, the values of sugar contents in fresh red carrotswas $8.62 \%$ in which reducing sugars are the predominant sugars in both cultivars recording $6.80 \%$. Results also indicated that, both these categories of samples showed little changes in total sugars in spite of using different types of osmosis solution for pretreatment before the drying process. Meanwhile, the amount of reducing sugars just after processing ranged between 51.69 to $56.50 \%$ for osmosed dried red carrotssamples where, the corresponding values of non reducing sugars were about 13.51 and $14.40 \%$ for all osmo-dried redcarrots. The control carrots had less total sugars than the osmodehydrated samples. Results showed a little change in total, reducing and non reducing sugars during storage at ambient temperature up to 6 months of storage. These results are similar to that reported by Taiwo, et. al., (2001).

From Table (3) it could be also observed that, the values of ash and crude fibers incarrots were (1.20 and 2.53\%). The ash content forosmosed dried red carrotspretreated with various osmotic solutions just after processing recorded 3.41 $3.51 \%$ in all samples, respectively and greater decrease during storage of all samples up to 6 months was observed. While crude fibers ranged between $9.53-9.75 \%$ for osmo-dried red carrotssamples, respectively, but it was $9.33 \%$ for control dried carrots. On the other hand, a little gradual reduction of crude fibers was noticed with extending the shelf-life of both osmo-dried and control-dried carrots up to 6 months of storage at ambient temperature. 
Table 3. Effect of storage period up to 6 months at ambient temperature on physico-chemical properties of osmo-dried red carrotstreated with various

\begin{tabular}{|c|c|c|c|c|c|c|c|c|c|c|c|}
\hline \multicolumn{3}{|c|}{ Constituents } & Moisture \% & $\begin{array}{c}\text { Total } \\
\text { Solids } \\
\%\end{array}$ & $\begin{array}{c}\text { Ascorbic } \\
\text { acid } \\
\text { (mg/100g) }\end{array}$ & $\begin{array}{c}\text { Total } \\
\text { Acidity } \\
\%\end{array}$ & $\begin{array}{c}\text { Total } \\
\text { sugars } \\
\%\end{array}$ & $\begin{array}{l}\text { Reducing } \\
\text { sugars\% }\end{array}$ & $\begin{array}{c}\text { Non- } \\
\text { reducing } \\
\text { sugars\% }\end{array}$ & Ash \% & $\begin{array}{c}\text { Crud } \\
\text { fiber } \%\end{array}$ \\
\hline \multirow{7}{*}{ 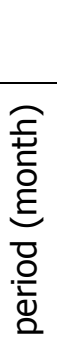 } & & $\begin{array}{l}\text { Fresh } \\
\text { carrots }\end{array}$ & 86.40 & 13.60 & 60.25 & 0.25 & 8.62 & 6.80 & 1.82 & 1.20 & 2.53 \\
\hline & \multirow{6}{*}{ 可 } & $\mathrm{T} 1$ & 15.75 & 84.25 & 90.15 & 1.11 & 65.20 & 51.69 & 13.51 & 3.41 & 9.75 \\
\hline & & $\mathrm{T} 2$ & 15.42 & 84.58 & 89.20 & 1.16 & 66.90 & 53.10 & 13.80 & 3.46 & 9.55 \\
\hline & & T3 & 15.30 & 84.70 & 93.62 & 1.18 & 68.80 & 54.70 & 14.10 & 3.49 & 9.50 \\
\hline & & T4 & 15.11 & 84.89 & 94.32 & 1.21 & 70.90 & 56.50 & 14.40 & 3.51 & 9.53 \\
\hline & & T5 & 15.88 & 84.12 & 96.45 & 1.01 & 64.21 & 49.90 & 13.31 & 3.36 & 9.33 \\
\hline & & $\mathrm{T} 1$ & 15.97 & 84.03 & 81.72 & 1.14 & 64.10 & 50.89 & 13.21 & 3.39 & 9.50 \\
\hline \multirow{9}{*}{ 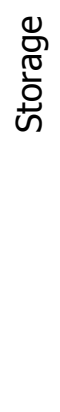 } & \multirow{3}{*}{ 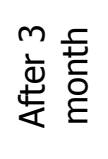 } & $\mathrm{T} 2$ & 15.83 & 84.17 & 83.62 & 1.18 & 65.21 & 51.49 & 13.72 & 3.44 & 9.42 \\
\hline & & T3 & 15.80 & 84.20 & 85.42 & 1.20 & 67.60 & 53.65 & 13.95 & 3.47 & 9.44 \\
\hline & & $\mathrm{T} 4$ & 15.40 & 84.60 & 88.23 & 1.24 & 69.11 & 54.85 & 14.26 & 3.48 & 9.47 \\
\hline & \multirow{6}{*}{ 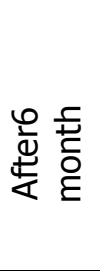 } & T5 & 16.01 & 83.99 & 90.12 & 1.11 & 64.70 & 51.50 & 13.20 & 3.33 & 9.27 \\
\hline & & $\mathrm{T} 1$ & 16.12 & 83.89 & 78.15 & 1.20 & 63.17 & 50.02 & 13.15 & 3.34 & 9.39 \\
\hline & & $\mathrm{T} 2$ & 15.91 & 84.09 & 79.92 & 1.22 & 63.90 & 50.28 & 13.62 & 3.41 & 9.36 \\
\hline & & T3 & 15.88 & 84.12 & 81.32 & 1.25 & 66.71 & 53.01 & 13.70 & 3.43 & 9.39 \\
\hline & & T4 & 15.70 & 84.30 & 84.15 & 1.27 & 67.45 & 53.25 & 14.20 & 3.44 & 9.41 \\
\hline & & T5 & 16.30 & 83.70 & 86.92 & 1.16 & 63.10 & 50.12 & 12.98 & 3.27 & 9.18 \\
\hline
\end{tabular}

$* *$ Values are the mean of three independent determinations 


\section{Microbiological assessment}

Table (4) shows the assessment of total microbial bacteria and the yeast and molds during storage ofosmo-driedred carrotspretreated by various osmotic solutions as well as the control-during storage up to 6 months at ambient temperature. The behaviour of the different groups of microorganisms (total microbial bacteria, yeast and molds) immediately after osmo dehydration and the control was quite different depending upon the type of pretreatment used before dehydration. The control carrots just after processing had the highest total microbial bacteria $\left(9.1 \times 10^{2} \mathrm{cfu} / \mathrm{g}\right)$ followed by $\left(3.3 \times 10^{2}, 5.2 \times 10^{2}, 3.7 \times 10^{2}\right.$ and $\left.2.6 \times 10^{2} \mathrm{cfu} / \mathrm{g}\right)$,for osmo-dried red carrotspretreated by immersing with syrups of $40,50,60 \%$ sucrose syrup and $70 \%$ sucrose syrup respectively. Results, also indicated that, yeast and molds in osmo dehydrated red carrotshad markedly lowest counts than the control samples depending upon the type of pretreatment with osmosis solution, where the total counts of yeast and molds micro bacteria ranged from $1.22 \times 10^{2}$ to $0.92 \times 10^{2} \mathrm{cfu} / \mathrm{g}$ for samples of osmodehydrated redcarrots. Thus, the pretreatment with osmosis solution before dehydration was more efficient for reduction either for total microbial bacteria or total counts of yeasts and molds. However, pretreatment with T4 and T3 for osmo-dried carrots were more effective and caused higher reduction of total counts followed by $\mathrm{T} 2$ and $\mathrm{T} 1$ respectively, immediately after processing of carrots. Meanwhile, osmodehydrated and the control sample of red carrotscaused gradual increment of reductions or eliminated for total viable counts in relation to the extending period of storage. Also, the viable microbial population gradually decreased during storage of samples tested by extending the time of storage which recorded the lowest total viable counts of total microbial bacteria, yeast and molds at the end of 6 months of storage. Subsequently, both total counts of bacteria and (yeast \& molds)bacteria growth decreased and reached the lowest level for all samples tested after 6 months of storage at ambient temperature compared with those values just after processing. In other words, the inactivation and/or the death of all tested counts of microorganisms showed to be proportional with extending the storage time and reached the maximum reduction after 6 months of storage. This trend of decreasing for total microbial counts, yeast and molds was correlated well with the type of osmotic solution used in pretreatment before dehydration, and extended storage period. 
Table 4. Population of total microbial bacteria and yeasts \& molds for Osmo-driedred carrotspretreated with various osmotic solutions during storage for 6 month at ambient temperature

\begin{tabular}{|c|c|c|c|c|}
\hline \multirow{2}{*}{\multicolumn{3}{|c|}{ Parameters }} & \multicolumn{2}{|c|}{ Redcarrots } \\
\hline & & & \multirow{2}{*}{$\begin{array}{c}\text { Total count } \\
(\mathrm{cfu} / \mathrm{g})\end{array}$} & \multirow{2}{*}{$\begin{array}{c}\begin{array}{l}\text { Yeast\& mold } \\
\text { count }(\mathrm{cfu} / \mathrm{g})\end{array} \\
1.22 \times 10^{2}\end{array}$} \\
\hline \multirow{15}{*}{ 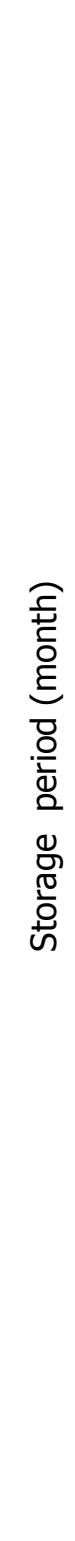 } & \multirow{5}{*}{ 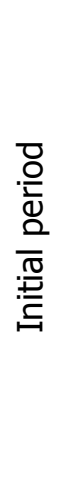 } & $\mathrm{T} 1$ ( $40 \%$ sucrose) & & \\
\hline & & $\mathrm{T} 2$ ( $50 \%$ sucrose) & $5.2 \times 10^{2}$ & $1.10 \times 10^{2}$ \\
\hline & & T3( 60\% sucrose) & $3.7 \times 10^{2}$ & $0.98 \times 10^{2}$ \\
\hline & & T4( $70 \%$ sucrose) & $2.6 \times 10^{2}$ & $0.92 \times 10^{2}$ \\
\hline & & T5( control ) & $9.1 \times 10^{2}$ & $1.94 \times 10^{2}$ \\
\hline & \multirow{5}{*}{ 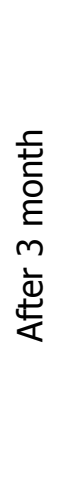 } & T1( $40 \%$ sucrose) & $5.2 \times 10^{2}$ & $1.12 \times 10^{2}$ \\
\hline & & $\mathrm{T} 2$ ( $50 \%$ sucrose) & $4.1 \times 10^{2}$ & $0.94 \times 10^{2}$ \\
\hline & & T3( $60 \%$ sucrose) & $2.8 \times 10^{2}$ & $0.90 \times 10^{2}$ \\
\hline & & T4( $70 \%$ sucrose) & $2.0 \times 10^{2}$ & $0.83 \times 10^{2}$ \\
\hline & & T5 ( control) & $7.9 \times 10^{2}$ & $1.54 \times 10^{2}$ \\
\hline & \multirow{5}{*}{ 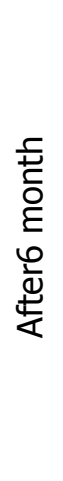 } & $\mathrm{T} 1$ ( $40 \%$ sucrose) & $3.4 \times 10^{2}$ & $0.98 \times 10^{2}$ \\
\hline & & $\mathrm{T} 2$ ( $50 \%$ sucrose) & $3.2 \times 10^{2}$ & $0.82 \times 10^{2}$ \\
\hline & & T3( $60 \%$ sucrose) & $2.1 \times 10^{2}$ & $0.73 \times 10^{2}$ \\
\hline & & T4( $70 \%$ sucrose) & $1.5 \times 10^{2}$ & $0.70 \times 10^{2}$ \\
\hline & & T5 ( control) & $4.6 \times 10^{2}$ & $1.00 \times 10^{2}$ \\
\hline
\end{tabular}

$* *$ Values are the mean of three independent determinations $* * * \mathrm{cfu}=$ colony forming unit 


\section{Sensory evaluation of osmo-dried redcarrots:}

The analysis of variance for color, texture, taste, flavour and overall acceptability for the processed red carrotsjust after processing and during storage up to 6 month at ambient temperature are shown is Table (5). Analysis of variance indicated that a significant difference in color, texture, taste, flavor and overall acceptability averaged between dehydrated samples tested correlated well with the type of osmotic syrups used for pretreatment of osmo-dried redcarrots. Also, a little significant difference averaged between samples pretreated with syrups of T3 (60\% sucrose) and T4 (70\%sucrose syrups) just after processing and by extending the shelf life up to 6 months. Osmo-dried carrots pretreated with $70 \%$ sucrose syrup recorded the highest values of sensory attributes followed by $60 \%$ sucrose, $50 \%$ sucrose and $40 \%$ sucrose respectively compared with the control dried red carrotswhich recorded the lowest sensory scores. Consequently, there were significant differences between osmo-dried carrots samples stored for 0,3 and 6 months at ambient temperature depeningupon the type of treatment used and extending the shelf life. On the other hand, the osmodehydrated red carrotspretreated by $70 \%$ sucrose had the highest scores of all tested sensory parameters followed by that pretreated with $60 \%, 50 \%, 40 \%$ sucrose syrup and the control respectively. Therefore, it seems that the decline of sensory scores was pronounced for control-dried samples stored for 6 months compared with those for theosmo-dried redcarrots.

Table 5. Sensory evaluation of dried and osmo-dried red carrots during storage for 6 month at ambient temperature

\begin{tabular}{|c|c|c|c|c|c|c|c|}
\hline \multicolumn{3}{|c|}{$\begin{array}{l}\text { Osmotic solution used } \\
\text { before dehydration process }\end{array}$} & $\begin{array}{c}\text { T1 } \\
40 \% \\
\text { sucrose }\end{array}$ & $\begin{array}{c}\text { T2 } \\
50 \% \\
\text { sucrose }\end{array}$ & $\begin{array}{c}\text { T3 } \\
60 \% \\
\text { sucrose }\end{array}$ & $\begin{array}{l}\text { T4 } \\
70 \% \\
\text { sucrose }\end{array}$ & $\begin{array}{l}\text { T5 } \\
\text { control }\end{array}$ \\
\hline \multicolumn{8}{|c|}{ Carrots } \\
\hline \multirow{15}{*}{ 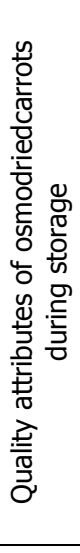 } & \multirow{5}{*}{ 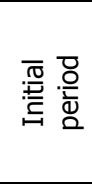 } & Color & $7.0^{c}$ & $7.4^{\mathrm{c}}$ & $8.6^{\mathrm{b}}$ & $9.6^{\mathrm{a}}$ & $6.1^{d}$ \\
\hline & & Texture & $7.1^{\mathrm{c}}$ & $7.4^{\mathrm{c}}$ & $8.4^{b}$ & $9.2^{\mathrm{a}}$ & $6.2^{d}$ \\
\hline & & Taste & $7.3^{c}$ & $7.5^{c}$ & $8.2^{\mathrm{b}}$ & $9.1^{\mathrm{a}}$ & $6.0^{d}$ \\
\hline & & Flavour & $7.1^{\mathrm{c}}$ & $7.1^{\mathrm{b}}$ & $8.2^{b}$ & $8.6^{\mathrm{ab}}$ & $6.0^{d}$ \\
\hline & & Overall acceptability & $7.2^{c}$ & $7.3^{c}$ & $8.1^{\mathrm{b}}$ & $9.2^{\mathrm{a}}$ & $6.1^{d}$ \\
\hline & \multirow{5}{*}{ 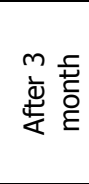 } & Color & $6.7^{c}$ & $7.3^{c}$ & $8.3^{b}$ & $8.6^{\mathrm{b}}$ & $5.9^{d}$ \\
\hline & & Texture & $6.8^{c}$ & $7.2^{c}$ & $8.2^{b}$ & $8.7^{b}$ & $5.8^{d}$ \\
\hline & & Taste & $6.6^{c}$ & $7.1^{\mathrm{c}}$ & $8.1^{\mathrm{b}}$ & $8.8^{\mathrm{b}}$ & $5.9^{d}$ \\
\hline & & Flavor & $6.7^{c}$ & $7.1^{\mathrm{c}}$ & $7.9^{c}$ & $8.5^{b}$ & $5.8^{d}$ \\
\hline & & Overall acceptability & $6.6^{c}$ & $7.0^{c}$ & $7.6^{c}$ & $8.6^{\mathrm{b}}$ & $5.7^{d}$ \\
\hline & \multirow{5}{*}{ 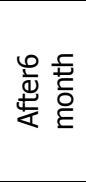 } & Color & $6.6^{c}$ & $6.9^{c}$ & 7.7 & $8.3^{b}$ & $5.8^{\mathrm{d}}$ \\
\hline & & Texture & $6.5^{\mathrm{cd}}$ & $6.9^{c}$ & $7.5^{c}$ & $8.4^{b}$ & $5.6^{d}$ \\
\hline & & Taste & $6.3^{c}$ & $6.4^{\text {cd }}$ & $7.4^{\mathrm{c}}$ & $8.3^{b}$ & $5.7^{d}$ \\
\hline & & Flavor & $6.2^{d}$ & $6.5^{d}$ & $7.6^{c}$ & $8.2^{b}$ & $5.6^{d}$ \\
\hline & & Overall acceptability & $6.5^{c}$ & $6.8^{\mathrm{c}}$ & $7.5^{\mathrm{c}}$ & $8.2^{b}$ & $5.7^{d}$ \\
\hline
\end{tabular}

Mean with different symbols in the horizontal columns significantly different at $P \leq 0.05$. 


\section{REFERENCES}

1. A P H A (American Public Health Association) 1992. Compendium Methods for the Microbiological Examination for Foods, PP. 75-97, 239-250 and 325-420. APHA, Washington, D.C.U.S.A.

2. Alasalvar C., J. M. Grigor, D. Zhang, P. C. Quantick and F. Shahidi. 2001. Comparison of volatiles, phenolics, sugars, antioxidant vitamins and sensory quality of different colored carrots varieties. Journal of Agriculture and Food Chemistry, 49(3): 1410-1416.

3. AOAC. 1995. Official Methods of Analysis 16th ed. Assos. Official Anal. Chem. Washington, D.C., USA.

4. Giangiacomo, R., D. Torreggiani and E. Abbo. 1987. Osmotic dehydration of fruit: Part 1. sugars exchange between fruit and extracting syrups. J. Food Processing and Preservation. 11:183-195.

5. Gornicki k. and A. Kaleta. 2007. Drying curve modeling of blanched carrots cubes under natural convection condition. J Food Eng 82, 160-170.

6. Hou D. X. 2003. Potential mechanisms of cancer chemoprevention by anthocyanins. Current Molecular Medicine, 3: 149-159.

7. Lerici, C.R., G. Pinnavaia, M. D. Dalla and L. Bartolucci. 1985. Osmotic dehydration of fruit: Influence of osmotic agents on drying behavior and product quality. J. Food Sci. 50:1217-1219\& 1226.

8. Matusek A., P. Meresz. 2002. Modelling of sugar transfer during osmotic dehydration of carrots. PeriodicaPolytechnica Series ChemEng 16, 83-92.

9. Netzel M., G. Netzel, D. R. Kammerer, A. Schieber, R. Carle, L. Simons, I. Bitsch R. Bitsch and I. Konczak. 2007. Cancer cell antiproliferation activity and metabolism of red carrotsanthocyaninsInnovative. Food Science and Emerging Technologies, 8: 365-37

10. Paakkomen, K. and M. Mattila. 1991. Processing, packging storage effects on quality of freeze-dried strawberries, J. of Food Sci. 56(5):1388-1392.

11. Rastogi, K., C. A. Nayak, K.S.M.S. Raghavarao. 2004. Influence of osmotic pretreatments on rehydration characteristics of carrots. J Food Eng 65, 287-292.

12. Revaskar V., G.P. Sharma, R.C. Verma, S.K. Jain, V.K. Chahar. 2007. Dryingbehaviour and energy requirement for dehydration of white onion slices. Int J Food Eng 14:253-262.

13. Salem, S. A. and S. M. Hegazi. 1973. Chemical changes occurring during the processing of dried apricot juice.J. Sci. Food Agric.,24:123-126. 
14. SAS, Statistical Analysis System. 1996. "SAS" User's Guide: Statistics, SAS. Institute Ins. Cary, NC, USA.

15. Schwarz, M., V. Wray and P. Winterhalter. 2004. Isolation and identification of novel pyranoanthocyanins from red carrots (DaucuscarotaL.) juice. Journal of Agriculture and FoodChemistry 52: 5095-5101.

16. Shastry A.V. and R. W. Hartel. 1996. Crystallization of thin films of sucrose solution during drying panning. J. Food Sci. 61:978-981.

17. Singh B., P.S. Panesar, V. Nanda, A.K. Gupta, J. F. Kenndy. 2006. Application of response surfacemethodology for the osmotic dehydration of carrots. J Food Process Eng 29, 592-614.

18. Stintzing F. C., Stintzing A. C., Carle B., B. Frei and R. E. Wrolstad. 2002. Color and antioxidantproperties of cyanidin-based anthocyanin pigments. Journal of Agriculture and Food Chemistry, 50,6172-6181.

19. Taiwo, K.A., A. Angersback, B.I.O. Ade-Omowaye and D. Knorr. 2001. Effect of pretreatment on diffusion kinetics and some quality parameters of osomotically dehydrated apple slices.J. Food and Agric. Chem. 49:2804-2811.

20. Tedjo, W., K.A. Taiwo, M.N. Eshtioghi and D. Knorr. 2002. Comparison of pretreatment methods on water and solid diffusion kinetics of osmotically dehydrated mangos. J Food Engineering 53:133-142.

21. Valia, M. J. V., F. C. Romero, R. M. Martinez and B. P. Penelas. 2009. Dehydration kinaetics of carrots (Daucuscarota L.) in osmotic and air convective drying process. Spanish Journal of Agricultural Research. 7: 869-875.

22. Yoshida K., T. Kondo and T. Goto. 1991. Unusually stable monoacylated anthocyanin from purple yam Discoreaalata. Tetrahedron Letters, 32: 5579-5580. 


\title{
تأثثر التجفيف الأسموزي علي الخواص الطبيعية والكيميائية للجزر الأحمر
}

\author{
قدري حامد محمد الوصيف، محم رمضان محمد مسعود، السيد محمود الصعيدي
}

\author{
معرج بحوث تكنولوجيا الاغذية - مركز البحوث الزراعية
}

أجريت هذه الدراسة بهدف تقييم عينات الجزر المنتج بالتجفيف الأسموزي والمعامل بتركيزات مختلفة من السكروز 40\% و 50\% و 60\% 70\% سكروز ومقارنتها بالعينة الغير معاملة (كنترول).

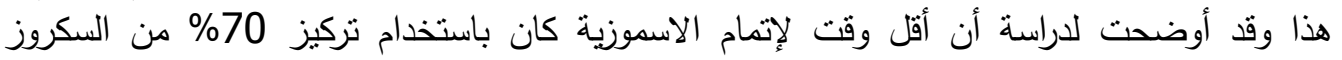

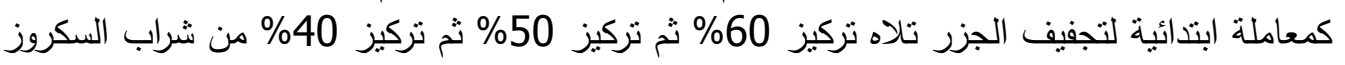

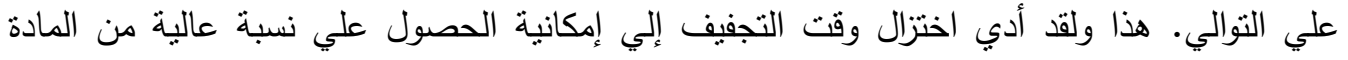

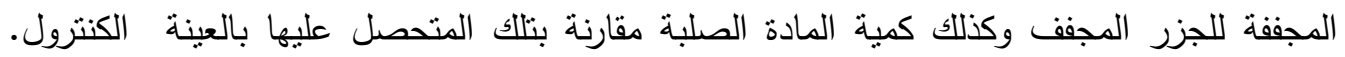

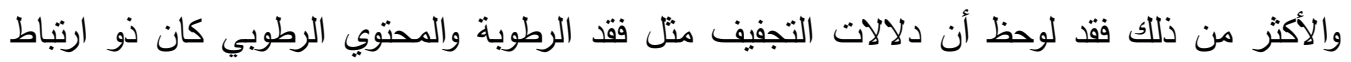

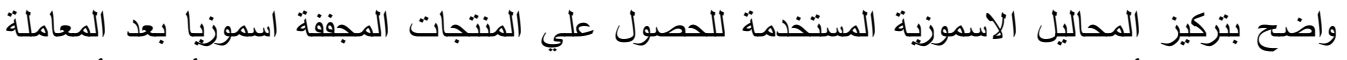

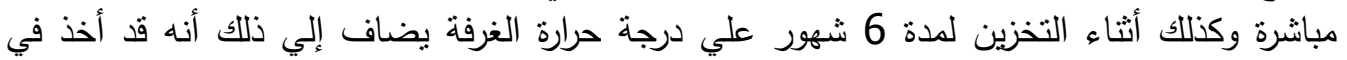

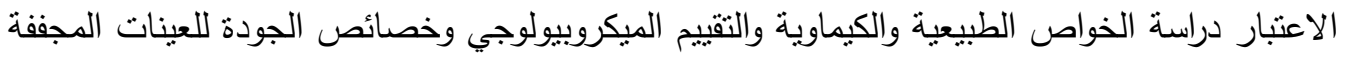

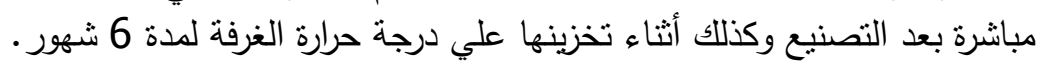

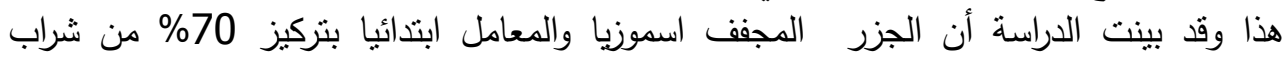

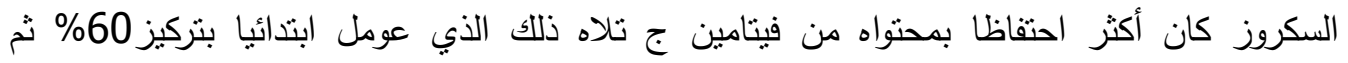

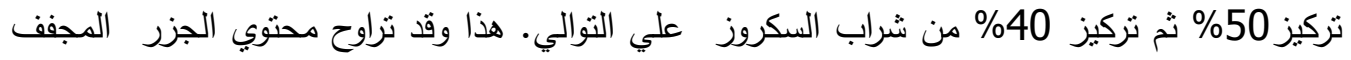

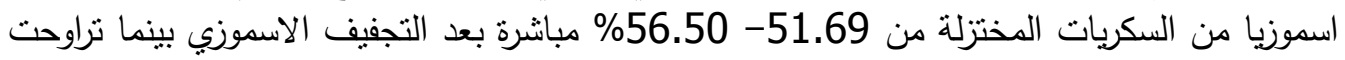

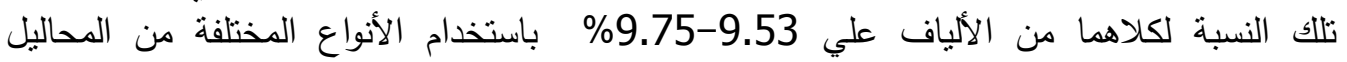

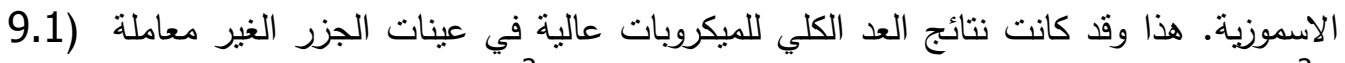

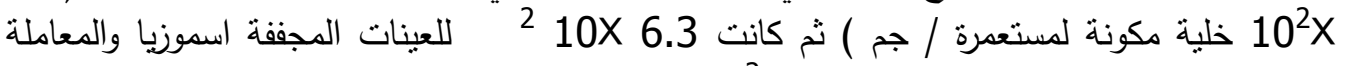

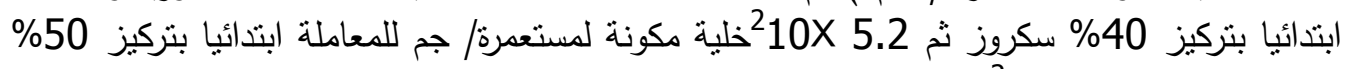

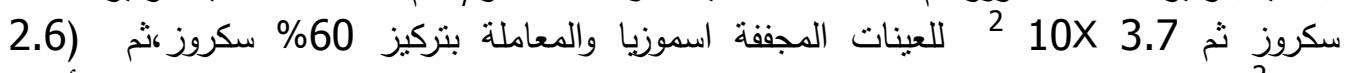

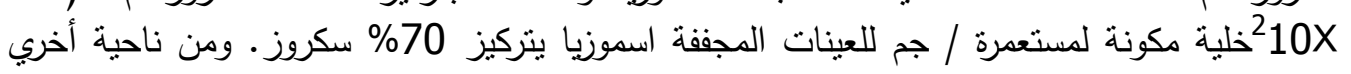
فلقد لوحظ من الدراسة حدوث انخفاض تدريجي في المحتوي الميكروبي الكلي وكذللك الفطر والخميرة

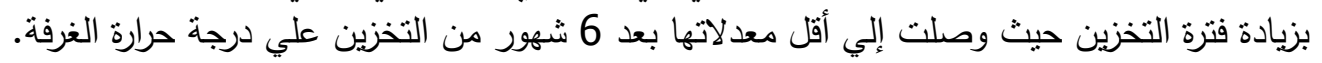

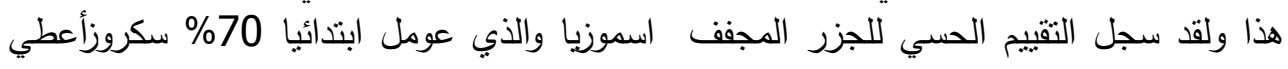

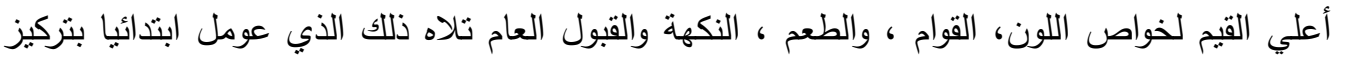

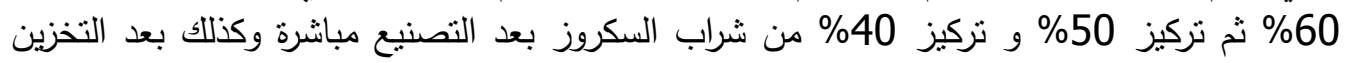

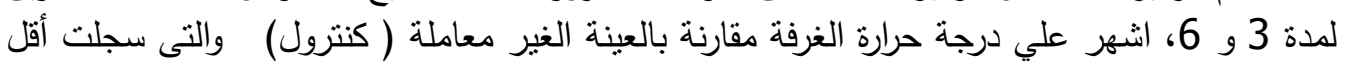
القيم في خصائص التقييم الحسي. وعلي ذلك فقد أوضحت الدراسة أن المعاملة الابتدائية بالمحاليل السكرية الاسموزية لإنتاج منتجات

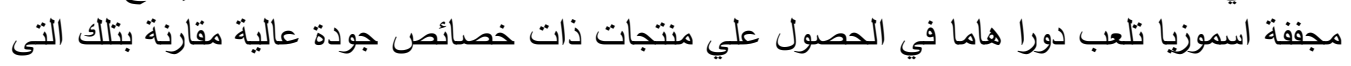

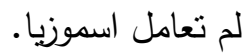

